\title{
Protective Mechanical Ventilation during General Anesthesia for Open Abdominal Surgery Improves Postoperative Pulmonary Function
}

\author{
Paolo Severgnini, M.D., ${ }^{*}$ Gabriele Selmo, M.D., ${ }^{*}$ Christian Lanza, M.D., ${ }^{\star}$ Alessandro Chiesa, M.D., ${ }^{*}$ \\ Alice Frigerio, M.D., ${ }^{\star}$ Alessandro Bacuzzi, M.D., ${ }^{*}$ Gianlorenzo Dionigi, M.D., Ph.D., $\neq$ \\ Raffaele Novario, P.H., § Cesare Gregoretti, M.D., || Marcelo Gama de Abreu, M.D., Ph.D.,\#

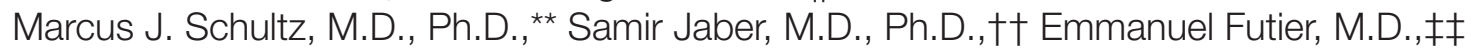 \\ Maurizio Chiaranda, M.D., Ph.D., §§ Paolo Pelosi, M.D., ||||
}

\begin{abstract}
Background: The impact of intraoperative ventilation on postoperative pulmonary complications is not defined. The authors aimed at determining the effectiveness of protective mechanical ventilation during open abdominal surgery on a modified Clinical Pulmonary Infection Score as primary outcome and postoperative pulmonary function.

Methods: Prospective randomized, open-label, clinical trial performed in 56 patients scheduled to undergo elective open abdominal surgery lasting more than $2 \mathrm{~h}$. Patients were assigned by envelopes to mechanical ventilation with tidal volume of $9 \mathrm{ml} / \mathrm{kg}$ ideal body weight and zero-positive endexpiratory pressure (standard ventilation strategy) or tidal
\end{abstract}

* Medical Doctor, \$ Professor, Department of Ambient, Health and Safety, University of Insubria, Varese, Italy. $\dagger$ Department of Anesthesia, Azienda Ospedaliera Fondazione Macchi-Ospedale di Circolo, Varese, Italy. $\ddagger$ Associate Professor, Department of Surgical Sciences, University of Insubria. § Research Assistant, Department of Clinical and Biological Sciences, University of Insubria. \| Department of Emergency and Intensive Care CTO-M Adelaide Hospital, Turin, Italy. \# Professor, Department of Anesthesiology and Intensive Care Therapy, University Hospital Carl Gustav Carus, Dresden University of Technology, Dresden, Germany. ** Professor, Department of Intensive Care Medicine-Academic Medical Center Univerisity of Amsterdam, Amsterdam, The Netherlands. † Professor, Department of Critical Care and Anesthesiology, CHU Montpellier Hopital Saint Eloi, Montpellier Cedex, France. H Assistant Professor, Department of Anesthesiology and Critical Care, University Hospital of Clermont-Ferrand, Clermont-Ferrand, France. |||| Professor, Department of Surgical Sciences and Integrated Diagnostics, University of Genoa, Genoa, Italy.

Received from the Department of Science and High Technology, University of Insubria-Servizio di Anestesia Rianimazione, Ospedale di Circolo, Varese, Italy. Submitted for publication April 5, 2012 Accepted for publication December 19, 2012. Support was provided solely from institutional and/or departmental sources.

Address correspondence to Dr. Severgnini: Department of Ambient, Health and Safety, University of Insubria-Servizio di Anestesia Rianimazione, Ospedale di Circolo, viale Borri 57, 21100, Varese, Italy. paolo.severgnini@uninsubria.it. Information on purchasing reprints may be found at www.anesthesiology.org or on the masthead page at the beginning of this issue. Anesthesiology's articles are made freely accessible to all readers, for personal use only, 6 months from the cover date of the issue.

Copyright $\odot$ 2013, the American Society of Anesthesiologists, Inc. Lippincott Williams \& Wilkins. Anesthesiology 2013; 118:1307-21
What We Already Know about This Topic

- The use of large tidal volumes during mechanical ventilation of the lungs can injure the lungs of critically ill patients

What This Article Tells Us That Is New

- A prospective, randomized, open-label trial of protective ventilation in 56 patients undergoing more than $2 \mathrm{~h}$ of open abdominal surgery showed that lower tidal volumes, positive end-expiratory pressure, and recruitment maneuvers led to significantly improved pulmonary function test results up to 5 days after surgery, fewer chest $\mathrm{x}$-ray findings and improved Clinical Pulmonary Infection Scores

volumes of $7 \mathrm{ml} / \mathrm{kg}$ ideal body weight, $10 \mathrm{~cm} \mathrm{H}_{2} \mathrm{O}$ positive end-expiratory pressure, and recruitment maneuvers (protective ventilation strategy). Modified Clinical Pulmonary Infection Score, gas exchange, and pulmonary functional tests were measured preoperatively, as well as at days 1, 3, and 5 after surgery.

Results: Patients ventilated protectively showed better pulmonary functional tests up to day 5 , fewer alterations on chest $\mathrm{x}$-ray up to day 3 and higher arterial oxygenation in air at days 1,3 , and $5(\mathrm{mmHg}$; mean $\pm \mathrm{SD})$ : $77.1 \pm 13.0$ versus $64.9 \pm 11.3(P=0.0006), 80.5 \pm 10.1$ versus $69.7 \pm 9.3$ $(P=0.0002)$, and $82.1 \pm 10.7$ versus $78.5 \pm 21.7(P=0.44)$ respectively. The modified Clinical Pulmonary Infection Score was lower in the protective ventilation strategy at days 1 and 3. The percentage of patients in hospital at day 28 after surgery was not different between groups (7 vs. 15\% respectively, $P=0.42$ ).

Conclusion: A protective ventilation strategy during abdominal surgery lasting more than $2 \mathrm{~h}$ improved respiratory function and reduced the modified Clinical Pulmonary Infection Score without affecting length of hospital stay.

- This article is accompanied by an Editorial View. Please see: Vidal Melo MF, Eikermann M: Protect the lungs during abdominal surgery: It may change the postoperative outcome. ANESTHESIOLOGY 2013; 118:1254-7. 
P OSTOPERATIVE pulmonary complications, especially postoperative respiratory failure, are important causes of perioperative morbidity and mortality. ${ }^{1-4}$ Induction of general anesthesia promotes a reduction in lung volume and atelectasis formation associated with a deterioration of both gas exchange and respiratory mechanics. ${ }^{5,6}$ There is unequivocal evidence from both experimental and clinical studies that mechanical ventilation in critically ill patients has the potential to aggravate or even initiate lung injury. Two retrospective studies ${ }^{7,8}$ and one randomized controlled trial $^{9}$ suggested that lower tidal volumes are beneficial in patients who need long-term mechanical ventilation but do not suffer from lung injury.

Mechanical ventilation is mandatory in patients undergoing general anesthesia. Higher tidal volumes may overdistend noninjured lungs, in particular, nondependent lung tissue. During surgical procedures, both phenomena may stress the noninjured lung, triggering local inflammation and local coagulation. ${ }^{10,11}$ Retrospective and prospective studies have shown possible beneficial effects of lower tidal volumes in patients who are on short-term mechanical ventilation because of surgery. ${ }^{12,13}$ However, the beneficial effects of short-term intraoperative mechanical ventilation with lower tidal volumes on pulmonary integrity remains undefined. ${ }^{14,15}$ In addition, zero-positive end-expiratory pressure (ZEEP) or low levels of positive end-expiratory pressure (PEEP) may promote atelectasis, resulting in repetitive collapse/reopening of dependent lung tissue. The role of PEEP and low tidal volume (the so-called protective lung strategy) during the intraoperative period in preventing lung damage and postoperative pulmonary complications is not clearly defined. ${ }^{16,17}$ Indeed, recently an experimental study suggested that such strategy might even lead to increased inflammation and lung injury in normal lungs. ${ }^{18}$ Despite these pathophysiological considerations, the use of PEEP in the operating room is controversial. Recently, an observational study conducted in 28 centers in France revealed that most patients undergoing general surgery were ventilated without PEEP. ${ }^{19}$ Notably, the use of recruitment maneuvers (RMs) to open the lungs has also been found to improve the effectiveness of PEEP with regard to gas exchange during general anesthesia. ${ }^{20-22}$ However, to date, there is no clear evidence of an additional benefit of RMs for routine anesthesia.

The current study compared a lung-protective mechanical ventilation strategy combining the use of lower tidal volume $(\mathrm{Vt})$, higher PEEP levels, and intraoperative RMs, with a conventional standard mechanical ventilation (higher tidal volume, ZEEP without intraoperative RMs) during abdominal nonlaparoscopic surgery lasting more than $2 \mathrm{~h}^{1}$

We hypothesized that in patients with normal lungs scheduled for general anesthesia, a protective ventilation strategy might prevent lung function modifications and lung morphological alterations.

The aim was to determine in this patient population the effect of an intraoperative protective ventilation strategy on modifying chest x-ray images, oxygenation, and pulmonary functional tests.

\section{Materials and Methods}

\section{Study Design}

This unfunded, prospective, randomized, open-label, clinical trial was registered at ClinicalTrials.gov (ID NCT00426790). This trial was designed to demonstrate a superiority of treatment in protective group compared to the standard group.

The medical ethics committee of the Ospedale di Circolo e Fondazione Macchi, Varese, Italy, approved the trial protocol, and informed consent was obtained from all patients before inclusion. The trial was not overseen by an independent safety board monitoring due to its design as a pilot physiological study.

\section{Inclusion and Exclusion Criteria}

Patients scheduled for elective nonlaparoscopic abdominal surgery under general anesthesia from May 2006 to May 2008 were selected through the clinical anesthesia service of our regional university hospital-Azienda Ospedaliera Ospedale di Circolo e Fondazione Macchi of Varese, Italy.

Patients were eligible for participation if they met the following criteria: nonlaparoscopic abdominal surgery under general anesthesia expected to last more than $2 \mathrm{~h}$ and age more than 18 yr. Exclusion criteria were as follows: body mass index more than $40 \mathrm{~kg} / \mathrm{m}^{2}$, laparoscopic surgery, need for surgery in emergency, previous lung surgery (any), persistent hemodynamic instability, intractable shock considered unsuitable for the study by the patient's managing physician, history of chronic obstructive pulmonary disease, repeated systemic corticosteroid therapy for acute exacerbations of chronic obstructive pulmonary disease, asthma or sleep disorders, recent immunosuppressive medication defined as need of chemotherapy or radiation therapy, less than 2 months after chemotherapy or radiation therapy, severe cardiac disease defined as New York Heart Association class III or IV, or acute coronary syndrome, or persistent ventricular tachyarrhythmias, pregnancy (excluded by laboratory analysis), acute lung injury or acute respiratory distress syndrome, expecting to require prolonged postoperative mechanical ventilation, any neuromuscular disease, contraindications to position an epidural catheter because of major clotting disorders, ${ }^{23-25}$ or sign of infection at the site of the procedure. ${ }^{26}$

\section{Standard Procedures}

A central venous line was inserted in all patients, and a conservative fluids infusion $\left(12-15 \mathrm{ml} \cdot \mathrm{kg}^{-1} \cdot \mathrm{h}^{-1}\right)$ was administered during the study period to assure hemodynamic stability. Before they were given general anesthesia, patients underwent epidural anesthesia at the T8-T12 level whenever not contraindicated. After surgery the patients received a continuous infusion of ropivacaine $0.2 \%$ at $4-6 \mathrm{ml} / \mathrm{h}$ and morphine $0.1-0.15 \mathrm{mg}$ for at least $48 \mathrm{~h}$ (AmbIT PCA; Summit Medical Products, Inc., Sandy, UT) with the possibility of 
having patient-controlled bolus volume of $4-6 \mathrm{mg} / \mathrm{h}$. The catheter was scheduled to be removed on the fourth day after surgery. Removal of the epidural catheter was planned at least $12 \mathrm{~h}$ after the last dose of low-molecular weight heparin (Enoxaparine sodium 4,000 U/die in a single subcutaneous administration) and $4 \mathrm{~h}$ before the next administration.

In other patients analgesia was provided by subcutaneous continuous infusion through an elastomeric infusion system with morphine $(0.3-0.4 \mathrm{mg} / \mathrm{kg}$ in $24 \mathrm{~h})$ and ketorolac $(1.0-1.5 \mathrm{mg} / \mathrm{kg}$ in $24 \mathrm{~h})$ according to creatinine serum level. In only one patient analgesia was performed by a continuous intravenous infusion of ketorolac (60 mg in $24 \mathrm{~h}$ ) and tramadol $(300 \mathrm{mg}$ in $24 \mathrm{~h}$ ); rescue dose was provided by subcutaneous morphine $(5-10 \mathrm{mg})$. All patients were preoxygenated with $\mathrm{FIO}_{2} 0.8$ before tracheal intubation, and maintained at 0.4 during the entire anesthesia procedure, irrespective of study group, and received a routine anesthesia according to protocol, including intravenous fentanyl (1$3 \mu / \mathrm{kg})$, propofol $(2-3 \mathrm{mg} / \mathrm{kg})$ at induction; thereafter, anesthesia was maintained with propofol $\left(5-10 \mathrm{mg} \cdot \mathrm{kg}^{-1} \cdot \mathrm{h}^{-1}\right)$ or sevoflurane (inspiratory concentration between 1.5 and $2 \%)$; analgesia was provided with continuous remifentanil infusion $\left(0.05-0.3 \mu \cdot \mathrm{kg}^{-1} \cdot \mathrm{min}^{-1}\right)$ or fentanyl $(1-3 \mu / \mathrm{kg})$ as required. Patients were intubated after they were administered rocuronium bromide $(0.8 \mathrm{mg} / \mathrm{kg})$; rocuronium was administered every $40 \mathrm{~min}$, and the last administration was at least $1 \mathrm{~h}$ before the end of surgical suture. Routine intraoperative monitoring was performed using a dedicated monitor (IntelliVue Mp70; Philips Electronics, Eindhoven, The Netherlands) and included noninvasive blood pressure, pulse oximetry, end-tidal fractions of carbon dioxide, and electrocardiogram.

According to the standard of care in our institution all patients underwent conventional physiotherapy ${ }^{27}$ (early mobilization, stimulation of cough, and incentive spirometry), control of pain to achieve a Visual Analogue Scales (VAS) below 3, antibiotic prophylaxis, and antithrombotic treatment as required in the postoperative period.

\section{Ventilation Protocol}

Concealed randomization was conducted to ensure a fair comparison between groups: to select patients for treatment we generated a randomization list by Random Allocation Software (Windows software, version 1.0, May 2004, Saghaei, licensee BioMed Central Ltd.) (allocation ratio 1:1) and inserted the group-identification paper in envelopes, which were then sealed and clouded to not reveal allocations.

The ventilation protocol consisted of volume-controlled mechanical ventilation (Datex Ohmeda S/5 Avance; GE Healthcare, Helsinki, Finland) at an inspired oxygen fraction of 0.40 , inspiratory to expiratory ratio of $1: 2$, and a respiratory rate adjusted to normocapnia (end-tidal carbon dioxide partial pressure between 30 and $40 \mathrm{mmHg}$ ). The compliance value was calculated with the plateau pressure measured during the normal ventilation setting, with an inspiratory pause set at $40 \%$ of the inspiratory time. Patients were randomly assigned to mechanical ventilation with either a tidal volume of $9 \mathrm{ml} / \mathrm{kg}$ ideal body weight (IBW) and ZEEP (the standard ventilation strategy) or $7 \mathrm{ml} / \mathrm{kg} \mathrm{IBW}$ and $10 \mathrm{~cm} \mathrm{H}_{2} \mathrm{O}$ PEEP with RMs (the protective ventilation strategy). IBW was calculated according to a predefined formula: $50+0.91$ (height $[\mathrm{cm}]-152.4$ ) for men and $45.5+0.91$ (height $[\mathrm{cm}]$ -152.4) for women. ${ }^{28} \mathrm{RMs}$, as part of the protective strategy, were performed directly after induction of anesthesia, after any disconnection from the mechanical ventilator and directly before extubation, in hemodynamic stable situation as judged by the attending physician. Briefly, RMs were performed in volume-controlled ventilation as follows: the limit of peak inspiratory pressure was initially set at $45 \mathrm{~cm} \mathrm{H}_{2} \mathrm{O}$, the tidal volume at $7 \mathrm{ml} / \mathrm{kg} \mathrm{IBW}$, and respiratory rate at 6 breaths/min, PEEP at $10 \mathrm{~cm} \mathrm{H}_{2} \mathrm{O}$, and the inspiratory to expiratory ratio at $3: 1$; then the tidal volume was increased in steps of $4 \mathrm{ml} / \mathrm{kg}$ IBW until plateau pressure reached $30 \mathrm{~cm}$ $\mathrm{H}_{2} \mathrm{O}$ and three breaths were allowed. Finally, the respiratory rate, the inspiratory to expiratory ratio, inspiratory pause, and tidal volume were set back at values preceding the RM, whereas the PEEP was maintained at $10 \mathrm{~cm} \mathrm{H}_{2} \mathrm{O}$.

We defined a remarkable reduction in systolic arterial pressure when less than $90 \mathrm{mmHG}$ and ensured that a mean arterial pressure less than $60 \mathrm{mmHg}$ was not accepted.

Anesthesiologists were allowed to change the ventilation protocol at any point on the surgeon's request, or if there was any concern about patient safety.

\section{Clinical and Laboratory Variables}

During mechanical ventilation, airway pressures, tidal volume, and the respiratory rate were measured by means of the facilities of the ventilator. The compliance of the respiratory system was calculated as $\mathrm{V}_{\mathrm{T}} /$ (plateau pressure of the respiratory system - PEEP).

Before and after surgery, pulmonary functional tests were performed at the bedside by using a spirometer (FERRARIS PiKo-6 FEV1/FEV6 METER; Pulmonary Data Services, Inc., Louisville, KY) while the patient was in a seated, comfortable position. A clip was placed over the nose and the patient breathed through the mouth into a tube connected to the spirometer. First the patient breathed in deeply, and then exhaled as quickly and forcefully as possible into the tube. The patient repeated this test three times and the best of the three results was considered to be the measure of lung function. The forced vital capacity and the forced expiratory vital capacity in $1 \mathrm{~s}$ were measured whereas the ratio between the forced vital capacity and the forced expiratory vital capacity in $1 \mathrm{~s}$ (forced expiratory vital capacity in $1 \mathrm{~s} /$ forced vital capacity) was calculated by the internal algorithm of the spirometer. We also calculated the predicted values of pulmonary functional tests according to Quanjer et al. ${ }^{29}$

Arterial blood gas analysis (Copenhagen abl 700 series; Radiometer, Brønshøj, Denmark) and peripheral oxygen saturation were measured in sitting position in room air, after 
10 min of adaptation. After surgery, if the patient was using a Venturi oxygen mask (Breathing Solutions, Castelbolognese, Italy). the mask was removed. If peripheral oxygen saturation dropped below $88 \%$ during the 10 min of adaptation, the maneuver was stopped and arterial blood gas analysis immediately obtained.

\section{Pain Score}

Pre- and postoperative dyspnea, cough, presence of secretions, abdominal and thoracic pain were measured by means of specifically targeted VAS. VAS was obtained by an attending physician not involved in the study. Patients were asked to report their level of comfort by pointing to a horizontal line, $100 \mathrm{~mm}$ in length, anchored by word descriptor at each end, after answering one of the following questions: "How is your sensation of dyspnea?", "How severe was your cough today?", "How is your level of pain?"30,31 The VAS (in millimeters) was determined by measuring from the left-hand end of the line to the point that the patient or the physician marked.

\section{Chest Radiography}

Pre- and postoperative (day 1 and day 3) chest x-ray, performed at the bedside, was examined in a blinded way by an independent specialist in radiology, who was not involved in the study. Pathological chest $\mathrm{x}$-ray was defined as the presence of at least one of the following: atelectasis, pleural effusions, or other chest radiological alterations.

\section{Modified Clinical Pulmonary Infection Score}

The modified Clinical Pulmonary Infection Score (mCPIS) was calculated by a modified original score as described by Pelosi et al. ${ }^{32}$ Patients were also compared before and after surgery for the following parameters: the Glasgow Coma Scale for nervous central system, the mean arterial pressure or administration of vasopressors required for cardiovascular system, the serum aspartate transaminase, alanine transaminase, and bilirubin for liver, the prothrombin time and platelets for coagulation, and the serum creatinine for renal system. ${ }^{33}$

\section{Intraoperative Observations}

During the intraoperative period (after induction of anesthesia, during the surgery, and before extubation) the following data were collected: airway pressures, arterial pressure, compliance of the respiratory system, peripheral oxygen saturation, and end-tidal fractions of carbon dioxide. Intraoperative fluids requirement and erythrocytes administration were recorded, as well as blood losses and urine output. Intraoperative complications were recorded during anesthesia, and defined as follows: peripheral oxygen saturation less than $90 \%$ and/or end-tidal fractions of carbon dioxide more than $45 \mathrm{mmHg}$ for more than $1 \mathrm{~min}$, need to change the ventilation setting (tidal volume and/or respiratory rate), heart rate more than 100 beats/min or less than 60 beats/ min, systolic arterial pressure more than $150 \mathrm{mmHg}$ or less than $90 \mathrm{mmHg}$, need for vasoactive drugs. During RMs, noninvasive blood pressure measurements were performed by setting the monitor in continuous mode.

\section{Pre- and Postoperative Observations}

Preoperatively the following measurements were obtained: peripheral oxygen saturation and arterial blood gas analysis in air, pulmonary functional tests, tympanic temperature, VAS for abdominal and thoracic pain, dyspnea, cough, presence of secretions, laboratory tests for organ function, chest $\mathrm{x}$-ray, and the mCPIS.

The same measurements were performed on postoperative days 1,3 , and 5 whereas the chest $\mathrm{x}$-ray and the mCPIS were calculated only on postoperative days 1 and 3. Pulmonary complications were defined with Celli score ${ }^{34}$ calculated postoperatively on days 1,3 , and 5 .

Pulmonary complications were defined as the development of three or more of six new findings: cough, increased secretions, dyspnea, chest pain, temperature greater than $38^{\circ} \mathrm{C}$, and pulse rate more than 100 beats $/ \mathrm{min} .{ }^{34}$ Surgical complications were recorded and patients were followed up until hospital discharge or death. Wound infection was defined according to Horan et al. ${ }^{35}$ criteria: infection within 30 days after the operative procedure with at least purulent drainage from the superficial incision, organisms isolated from an aseptically obtained culture of fluid or tissue from the superficial incision, with pain or tenderness, localized swelling, redness or heat.

\section{Primary and Secondary Endpoints}

Our hypothesis was that intraoperative lung-protective ventilation could protect against postoperative pulmonary and extrapulmonary complications. The primary endpoints were the changes in mCPIS in the postoperative period. The secondary endpoints were the changes in arterial oxygenation and peripheral oxygen saturation in air, the pulmonary functional tests, and the rate of complications during recruitment, anesthesia, as well as in the postoperative period.

\section{Statistical Analysis}

The sample size was based on data previously published in the literature on oxygenation and chest x-ray alterations postoperatively, according to Hedenstierna and Edmark ${ }^{5}$ and Choi et al., ${ }^{10}$ but a formal a priori sample size calculation was not conducted.

The normality of the distribution was tested with the D'Agostino-Pearson test. Data are given as mean \pm SD or median and interquartile range (25-75\%), as appropriate. Comparisons of normally distributed variables were performed with paired or unpaired $t$ tests as appropriate, whereas the Mann-Whitney and the Wilcoxon tests were used for other variables. Comparisons of two or more proportions were conducted with the chi-square test; the Fisher exact test was used for small frequencies. The major outcome variables were tested with two-way repeated measures ANOVA (group 
effects), and pair-wise comparisons of each time point with baseline, adjusted according to Bonferroni correction, were conducted.

The Kaplan-Meier curve was used to analyze the length of hospital stay in groups; the log-rank test was used for the reported $P$ value.

All tests were two-tailed and statistical significance was accepted at $P$ value less than 0.05 .

All statistical analyses were performed with MedCalc Version 9.3.7.0 (MedCalc Software bvba, Mariakerke, Belgium). The statistical analysis was performed independently of the team of the clinicians involved in the study, by a specialist in physics and biomedical statistics (Dr. Novario).

\section{Results}

Five hundred twenty-seven consecutive patients, who were scheduled to undergo an elective surgical procedure of $2 \mathrm{~h}$ or more, were screened (fig. 1). Four hundred sixty-nine patients had one or more exclusion criteria, leaving 58 patients for randomization. Two patients were excluded because of change of surgical plan to videolaparoscopic surgery. Fifty-six were randomized. One patient assigned to standard ventilation was excluded due to a severe intraoperative surgical complication leading to a modification in the ventilator settings. Fifty-five patients entered the final analysis. There were no major differences between the two groups with regard to baseline characteristics (table 1).

\section{Intraoperative Observations}

During anesthesia, aside from the mechanical ventilator settings, there were no statistically significant differences between groups in intraoperative peripheral oxygen saturation, arterial pressure, and fluid balance (table 2). In the majority of cases anesthesiologists used sevoflurane to maintain anesthesia (26 of 28 cases for the protective ventilation

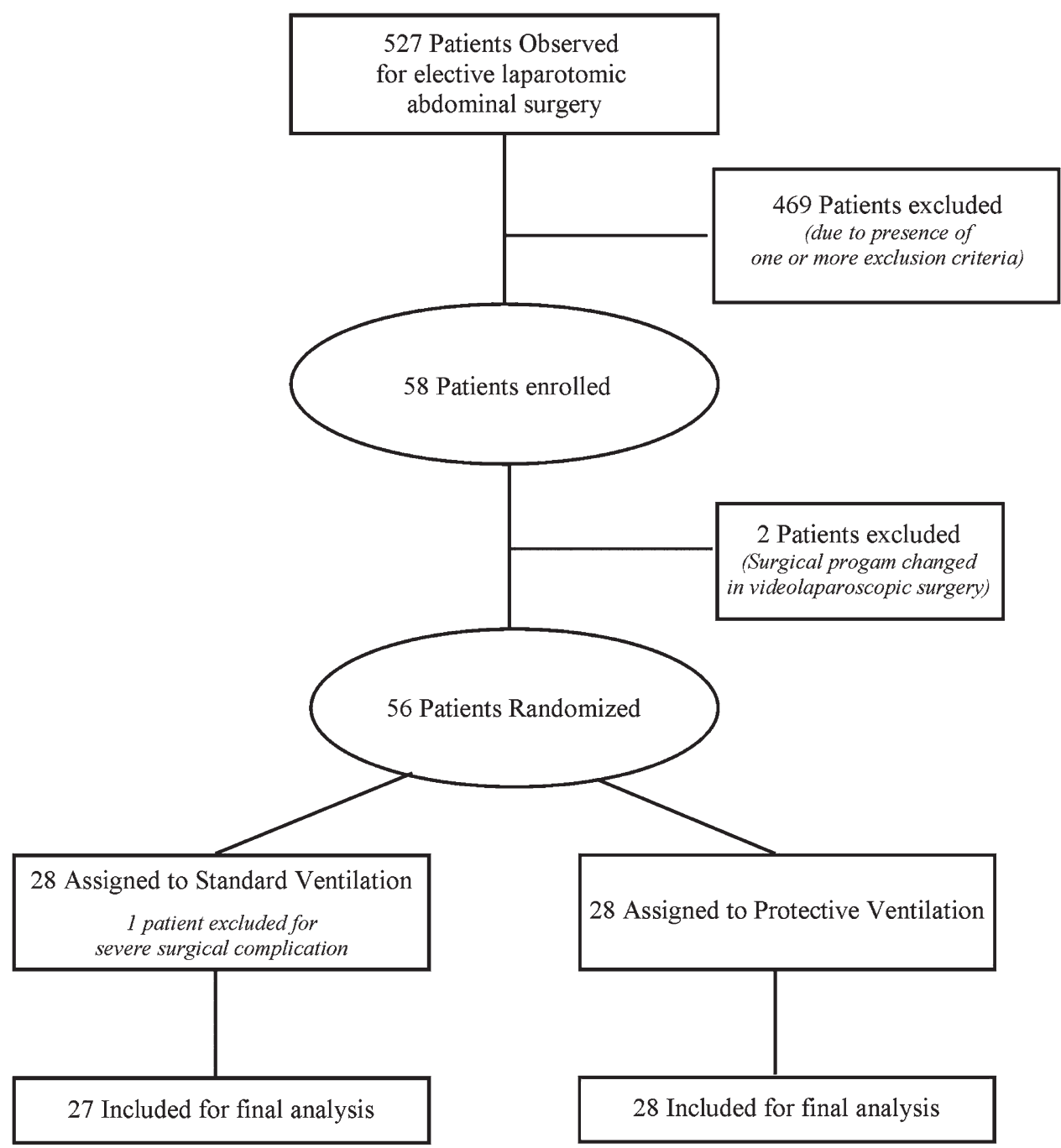

Fig. 1. Flow diagram summarizing inclusion, allocation, and analysis. Five hundred twenty-seven patients were observed during the study period; 469 patients were excluded due to the presence of one or more exclusion criteria. Fifty-eight patients were enrolled; two patients were excluded because of a change in surgical strategy, one patient was excluded for surgical complication, and finally 55 patients were included for analysis. 


\begin{tabular}{|c|c|c|c|}
\hline & $\begin{array}{l}\text { Standard Ventilation } \\
\qquad(\mathrm{n}=27)\end{array}$ & $\begin{array}{l}\text { Protective Ventilation } \\
\qquad(\mathrm{n}=28)\end{array}$ & $P$ Value \\
\hline Age, yr (mean \pm SD) & $67.0 \pm 9.0$ & $65.5 \pm 11.4$ & 0.94 \\
\hline Sex, M/F & $16 / 11$ & $18 / 10$ & 0.78 \\
\hline $\mathrm{BMI}, \mathrm{kg} / \mathrm{m}^{2}$ (mean $\left.\pm \mathrm{SD}\right)$ & $25.9 \pm 4.2$ & $25.0 \pm 4.9$ & 0.47 \\
\hline \multicolumn{4}{|l|}{ Physical status, n (\%) } \\
\hline ASA I & $4(14.8)$ & $6(21.3)$ & 0.73 \\
\hline ASA II & $21(77.8)$ & $19(67.9)$ & 0.55 \\
\hline ASA III & $2(7.4)$ & $3(10.7)$ & 1.0 \\
\hline History of tobacco use, n (\%) & $10(37.0)$ & $7(25.0)$ & 0.39 \\
\hline \multicolumn{4}{|l|}{ Type of surgery, n (\%) } \\
\hline Hepatic & $3(11.1)$ & $1(3.6)$ & 0.35 \\
\hline Biliary & $5(18.5)$ & $2(7.1)$ & 0.25 \\
\hline Gastrointestinal & $17(63.0)$ & $20(71.4)$ & 0.57 \\
\hline Other & $2(7.4)$ & $5(17.9)$ & 0.42 \\
\hline \multicolumn{4}{|l|}{ Type of postoperative analgesia, n (\%) } \\
\hline Epidural & $19(70.4)$ & $19(67.9)$ & 0.92 \\
\hline Subcutaneous elastomeric infusion system & $7(25.9)$ & $9(32.1)$ & 0.83 \\
\hline Intravenous & $1(3.7)$ & $0(0.0)$ & 0.99 \\
\hline
\end{tabular}

$\mathrm{ASA}=$ American Society of Anesthesiology; $\mathrm{BMI}=$ body mass index; $\mathrm{F}=$ female; $\mathrm{M}=$ male.

group and 26 of 27 cases for the standard ventilation group; $P=1.0)$. Tidal volume, PEEP, plateau pressure, and mean airway pressure of the respiratory system were higher in the protective group compared with the standard ventilation strategy group. The respiratory rate was slightly lower in the standard ventilation strategy group, whereas the end-tidal carbon dioxide partial pressure was slightly higher in the protective ventilation strategy group.

Overall intraoperative complications, including those during RMs, were comparable between the two study groups (table 3). During RMs in eight patients systolic arterial pressure decreased less than $90 \mathrm{mmHg}$ for more than $3 \mathrm{~min}$, whereas two patients showed a heart rate less than 60 beats/ min. No other complications were observed during RMs.
End-tidal carbon dioxide partial pressure was never less than $25 \mathrm{mmHg}$ during RMs.

\section{Postoperative Observations}

On postoperative days 1 and 3, the mCPIS was lower in the protective as compared with standard ventilation group (fig. 2 and table 4). Pulmonary complications ${ }^{34}$ were higher in the standard group compared with the protective group on postoperative day 1 (7 of 26 vs. 1 of 27 respectively, $P=$ 0.024 ), whereas no differences were found on day 2 ( 4 of 26 vs. 2 of 27 respectively, $P=0.42$ ) and day 3 (3 of 26 vs. 1 of 25 respectively, $P=0.61$ ).

Peripheral oxygen saturation and arterial oxygenation decreased on postoperative days 1 and 3 compared with

Table 2. Intraoperative Data

\begin{tabular}{|c|c|c|c|}
\hline & $\begin{array}{l}\text { Standard Ventilation } \\
\qquad(\mathrm{n}=27)\end{array}$ & $\begin{array}{l}\text { Protective Ventilation } \\
\qquad(\mathrm{n}=28)\end{array}$ & $P$ Value \\
\hline $\mathrm{V}_{\mathrm{T}} / \mathrm{IBW}, \mathrm{ml} / \mathrm{kg}$ (mean $\left.\pm \mathrm{SD}\right)$ & $9.5 \pm 1.1$ & $7.7 \pm 0.8$ & $<0.0001$ \\
\hline $\mathrm{RR}$, breath/min (mean $\pm \mathrm{SD}$ ) & $11.0 \pm 1.1$ & $12.8 \pm 2.2$ & $<0.0001$ \\
\hline $\mathrm{P}_{\max }$, median $[\mathrm{IQR}], \mathrm{cm} \mathrm{H}_{2} \mathrm{O}$ & $19.0[18.0-21.0]$ & $22.0[19.0-24.0]$ & $<0.0001$ \\
\hline Pplat, median [IQR], $\mathrm{cm} \mathrm{H}_{2} \mathrm{O}$ & $16.0[14.0-18.0]$ & $18.0[16.0-22.0]$ & $<0.0001$ \\
\hline Compliance, median [IQR], ml/cm $\mathrm{H}_{2} \mathrm{O}$ & $40.0[20.0-40.0]$ & $40.0[30.0-50.0]$ & 0.45 \\
\hline $\mathrm{Spo}_{2}$, median $[\mathrm{IQR}], \%$ & $99.0[99.0-100]$ & 99.0 [99.0-100] & 0.16 \\
\hline $\mathrm{ETCO}_{2}$, median $[\mathrm{IQR}], \mathrm{mmHg}$ & $30.0[28.0-31.0]$ & $33.0[30.0-35.0]$ & $<0.0001$ \\
\hline Duration of anesthesia, min (mean \pm SD) & $223.0 \pm 80.0$ & $193 \pm 64$ & 0.16 \\
\hline Intraoperative blood loss, median [IQR], ml/kg & $4.2[1.8-6.9]$ & $5.1[2.7-6.8]$ & 0.21 \\
\hline Intraoperative urine output, median [IQR], ml/kg & $5.9[3.3-10.4]$ & $7.5[5.3-10.3]$ & 0.37 \\
\hline Intraoperative fluid administration, median [IQR], ml/kg & $50.0[37.0-66.0]$ & $46.2[41.4-65.2]$ & 0.96 \\
\hline Patients receiving blood packed cells, n (\%) & $3(11.1)$ & $3(10.7)$ & 1.0 \\
\hline
\end{tabular}

$\mathrm{ETCO}_{2}=$ end-tidal carbon dioxide; IBW = ideal body weight; IQR = interquartile range; $\mathrm{P}_{\text {max }}=$ peak airway pressure; Pplat = plateau pressure; $\mathrm{RR}=$ respiratory rate; $\mathrm{SpO}_{2}=$ oxygen peripheral saturation; $\mathrm{V}_{\mathrm{T}}=$ tidal volume. 
Table 3. Intraoperative Complications (Including Those during Recruitment Maneuver)

\begin{tabular}{lccc}
\hline & $\begin{array}{c}\text { Standard Ventilation } \\
(\mathrm{n}=27)\end{array}$ & $\begin{array}{c}\text { Protective Ventilation } \\
(\mathrm{n}=28)\end{array}$ & $P$ Value \\
\hline $\mathrm{SpO}_{2}<90 \%, \mathrm{n}(\%)$ & 0 & 0 & - \\
$\mathrm{ETCO}_{2}>45 \mathrm{mmHg}, \mathrm{n}(\%)$ & 0 & $3(10.7)$ & 0.24 \\
$\mathrm{HR}>100$ beats/min, $\mathrm{n}(\%)$ & $3(11.1)$ & $1(3.6)$ & 0.35 \\
$\mathrm{HR}<60$ beats/min, $\mathrm{n}(\%)$ & $2(7.4)$ & $3(10.7)$ & 1.0 \\
$\mathrm{SAP}>150 \mathrm{mmHg}, \mathrm{n}(\%)$ & $3(11.1)$ & $3(10.7)$ & 1.0 \\
$\mathrm{SAP}<90 \mathrm{mmHg}, \mathrm{n}(\%)$ & $9(33.3)$ & $15(53.6)$ & 0.18 \\
Need vasoactive drugs, $\mathrm{n}(\%)$ & $1(3.7)$ & 0 & 1.0 \\
\hline
\end{tabular}

$\mathrm{ETCO}_{2}=$ end-tidal carbon dioxide; $\mathrm{HR}=$ heart rate; $\mathrm{SAP}=$ systolic arterial pressure; $\mathrm{SpO}_{2}=$ oxygen peripheral saturation .

preoperative period in standard while not in the protective ventilation strategy group (figs. 3 and 4). No differences were found in $\mathrm{PaCO}_{2}$ and $\mathrm{pH}$ between groups up to postoperative day 5 .

Pulmonary functional tests were comparable preoperatively in both groups (table 5). Forced vital capacity and forced expiratory vital capacity in $1 \mathrm{~s}$ were higher in protective ventilation strategy group as compared with standard ventilation strategy group on postoperative days 1,3 , and 5. As shown in table 6 , in protective compared with standard ventilation group dyspnea, secretions, and cough scores were not different between groups on postoperative days 1 , 3 , and 5. Chest x-ray changes were fewer on postoperative days 1 and 3 in protective compared with standard ventilation group (fig. 5 and table 7 ). Finally, pulmonary complications, as evaluated with the Celli score ${ }^{34}$ (table 8), were lower

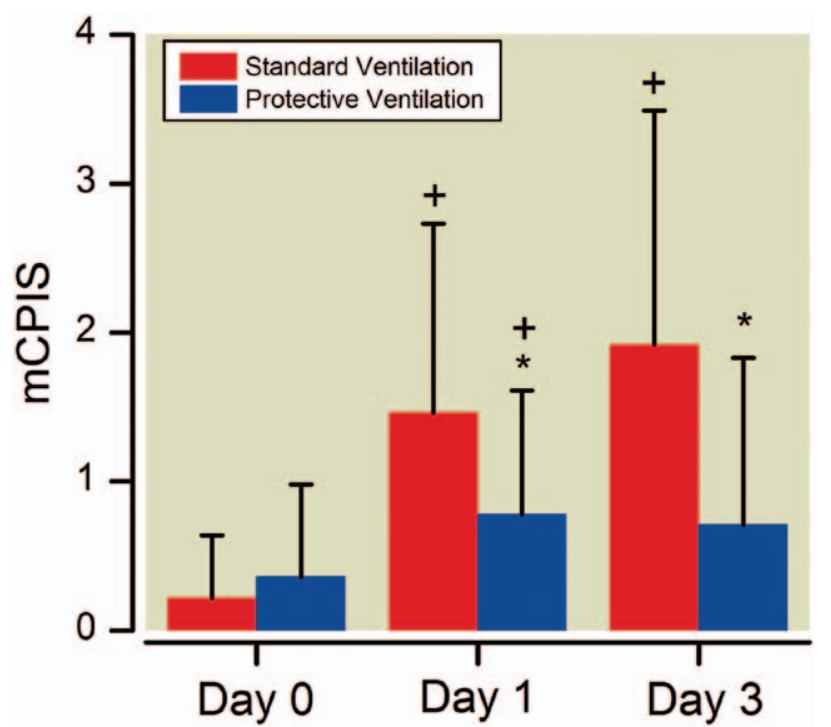

Fig. 2. Modified Clinical Pulmonary Infection Score (mCPIS) in standard (red bar) and protective (b/ue bar) ventilation group evaluated on days 0,1 , and $3 .{ }^{*} P<0.05$ versus standard ventilation group on days 1 and 3 ; within the same group ${ }^{\dagger} P<0.05$ versus preoperative period (day 0 ). Group effect over time $P=$ 0.001 . The individual pair-wise comparisons (Bonferroni corrected) show statistical significance as follows: mCPIS day 1 $P<0.0002$ versus day $0(95 \% \mathrm{Cl}, 0.3367-1.3232)$ and $\mathrm{mCPIS}$ day $3 P<0.0001$ versus day $0(95 \% \mathrm{Cl}, 0.5305-1.5169)$. in the protective ventilation group compared with standard ventilation group on postoperative day 1 .

No differences were observed in extrapulmonary organ function pre- and postoperatively between groups (table 9). Also there were no differences in fluids administration and hydric balance during postoperative period (table 10).

The Kaplan-Meier curve of hospital length of stay did not show statistically significant differences between groups (fig. 6; $P=0.96$; 95\% CI, 0.5775-1.7729). On postoperative day $28,7 \%$ of the patients in the protective ventilation strategy group as compared with $15 \%$ in the standard ventilation strategy group were still recovering in hospital ( 2 of 28 patients for protective ventilation group and 4 of 27 patients for the standard ventilation group, $P=0.42$ ).

None of the patients died and all were discharged home.

\section{Discussion}

In this randomized controlled trial, it was observed that in comparison to standard ventilation strategy with higher tidal volumes without PEEP and RMs, a lung-protective ventilation strategy with lower tidal volumes, $10 \mathrm{~cm} \mathrm{H}_{2} \mathrm{O}$ PEEP, and RMs (1) improved mCPIS on postoperative days 1 and 3; (2) improved postoperative arterial oxygenation and pulmonary functional tests; and (3) showed no association with an increased incidence of intraoperative complications or nonpulmonary organ failures.

Previous randomized controlled trials showed conflicting results regarding the influence of ventilator settings on surrogate endpoints of pulmonary and systemic inflammation. ${ }^{10,11,16,17,36-40}$ These studies were performed in cardiothoracic surgery, ${ }^{16,37-39,41}$ in esophagectomy, ${ }^{36}$ or in a nonhomogeneous groups of patients undergoing elective surgery. ${ }^{10,11,40}$ Most of them investigated only the effects on the inflammatory response $\mathrm{1}^{1,40}$ or alveolar coaugulopathy ${ }^{10}$ during mechanical ventilation. RMs were seldom applied in most of these studies, and the level of PEEP differed among trials. The current trial differs from previous investigations with regard to (1) the combination of lower tidal volumes, PEEP and RMs - none of the previous investigations evaluated potential complications of higher PEEP levels and RMs during general anesthesia; (2) the selected population 
Table 4. Criteria and Detail Score for Modified Clinical Pulmonary Infection Score on Days 1 and 3 Compared with Preoperative Period (Day 0)

\section{Day 0}

\begin{tabular}{|c|c|c|c|}
\hline Components & $\begin{array}{l}\text { Standard Ventilation } \\
\qquad(\mathrm{n}=27)\end{array}$ & $\begin{array}{l}\text { Protective Ventilation } \\
\qquad(\mathrm{n}=28)\end{array}$ & $P$ Value \\
\hline \multicolumn{4}{|l|}{ Temperature, ${ }^{\circ} \mathrm{C}, \mathrm{n}(\%)$} \\
\hline$\geq 36.1$ and $\leq 38.4$ & 27 (100) & $28(100)$ & 1.0 \\
\hline$\geq 38.5$ and $\leq 38.9$ & 0 & 0 & - \\
\hline$\geq 39.0$ and $\leq 36.0$ & 0 & 0 & - \\
\hline \multicolumn{4}{|l|}{ Blood leukocytes, n (\%) } \\
\hline$\geq 4000$ and $\leq 11.000$ & $26(96.3)$ & $25(89.3)$ & 0.61 \\
\hline$<4000$ and $>11.000$ & $1(3.7)$ & $3(10.7)$ & 0.31 \\
\hline \multicolumn{4}{|l|}{ Tracheal secretions, n (\%) } \\
\hline Few & 24 (88.9) & $26(92.8)$ & 0.67 \\
\hline Moderate & $3(11.1)$ & $1(3.6)$ & 0.35 \\
\hline Large & 0 & $1(3.6)$ & 1.0 \\
\hline Purulent & 0 & 0 & - \\
\hline \multicolumn{4}{|l|}{$\mathrm{PaO}_{2} / \mathrm{FIO}_{2}$ ratio, mmHg, $\mathrm{n}(\%)$} \\
\hline$>240$ or presence of ARDS & $27(100)$ & $28(100)$ & 1.0 \\
\hline$\leq 240$ and absence of ARDS & 0 & 0 & - \\
\hline \multicolumn{4}{|l|}{ Chest x-ray, n (\%) } \\
\hline No infiltrate & 25 (92.6) & 25 (89.3) & 1.0 \\
\hline Patchy or diffuse infiltrate & $2(7.4)$ & $3(10.7)$ & 1 \\
\hline Localized infiltrate & 0 & 0 & - \\
\hline
\end{tabular}

ARDS = acute respiratory distress symdrome; $\mathrm{FIO}_{2}=$ oxygen inspiratory fraction; $\mathrm{PaO}_{2}=$ oxygen arterial pressure .

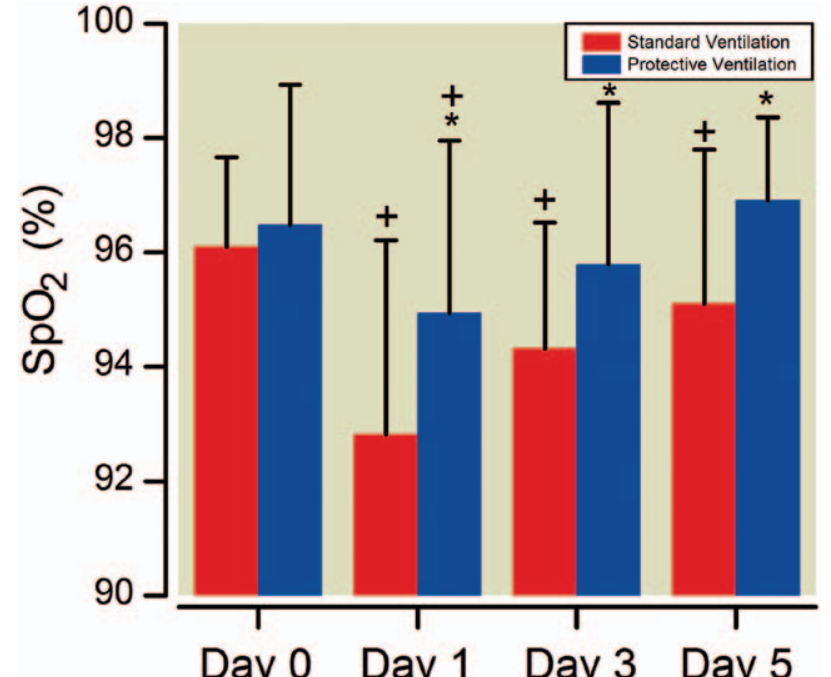

Fig. 3. Peripheral oxygen saturation $\left(\mathrm{Spo}_{2}\right)$ evaluated on postoperative days 1,3 , and 5 compared with the preoperative period (day 0) in standard (red bar) and protective (blue bar) ventilation strategy groups. * $P<0.05$ versus standard ventilation group on days 1,3 , and 5 , respectively; within the same group $+P<0.05$ versus preoperative period (day 0). Group effect over time $P<0.001$. The individual pair-wise comparisons (Bonferroni corrected) show statistical significance as follows: $\mathrm{Spo}_{2}$ day $1, P<0.0001$ versus day $0(95 \% \mathrm{Cl}$, -3.7065 to -1.1086$) ; \mathrm{Spo}_{2}$ day $3, P<0.0715$ versus day 0 $(95 \% \mathrm{Cl},-2.5362$ to 0.06174$) ; \mathrm{Spo}_{2}$ day $5, P=1.0$ versus day 0 (95\% Cl, -1.5850 to 1.0254$)$.

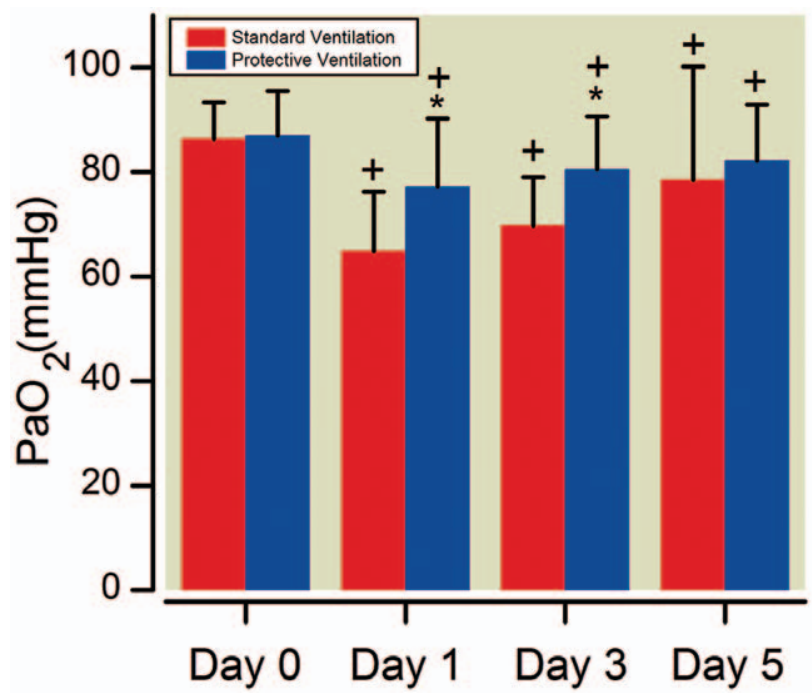

Fig. 4. Arterial oxygen pressure $\left(\mathrm{PaO}_{2}\right)$ evaluated on postoperative days 1,3 , and 5 compared with the preoperative period (day 0 ) in standard (red bar) and protective (blue bar) ventilation strategy groups. ${ }^{*} P<0.05$ versus standard ventilation group on days 1,3 , and 5 , respectively; within the same group $+P<0.05$ versus preoperative period (day 0 ). Group effect over time $P<0.001$. The individual pair-wise comparisons (Bonferroni corrected) show statistical significance as follows: $\mathrm{PaO}_{2}$ on day $1 P<0.0001$ versus on day $0(95 \% \mathrm{Cl}, 21.8521$ to -9.3786); $\mathrm{PaO}_{2}$ on day $3 \mathrm{P}<0.0001$ versus on day $0(95 \% \mathrm{Cl}$, 17.7832 to -5.3096$) ; \mathrm{PaO}_{2}$ on day $5 P<0.046$ versus on day 0 (95\% Cl, 12.6022 to -0.06890$)$. 
Table 4. (Continued)

\begin{tabular}{|c|c|c|c|c|c|}
\hline \multicolumn{3}{|c|}{ Day 1} & \multicolumn{3}{|c|}{ Day 3} \\
\hline $\begin{array}{l}\text { Standard Ventilation } \\
\qquad(\mathrm{n}=26)\end{array}$ & $\begin{array}{c}\text { Protective Ventilation } \\
\qquad(n=27)\end{array}$ & $P$ Value & $\begin{array}{l}\text { Standard Ventilation } \\
\qquad(\mathrm{n}=26)\end{array}$ & $\begin{array}{l}\text { Protective Ventilation } \\
\qquad(\mathrm{n}=27)\end{array}$ & $P$ Value \\
\hline 26 (100) & 27 (100) & 1.0 & 26 (100) & 27 (100) & 1.0 \\
\hline 0 & 0 & - & 0 & 0 & - \\
\hline 0 & 0 & - & 0 & 0 & - \\
\hline $16(61.5)$ & $20(74.1)$ & 0.39 & 20 (76.9) & 24 (88.9) & 0.29 \\
\hline $10(38.5)$ & 7 (25.9) & 0.38 & $6(23.1)$ & $3(11.1)$ & 0.29 \\
\hline $16(61.5)$ & $21(77.8)$ & 0.24 & 14 (53.8) & $21(77.8)$ & 0.08 \\
\hline 6 (23.1) & $3(11.1)$ & 0.29 & $4(15.4)$ & $3(11.1)$ & 0.70 \\
\hline $4(15.4)$ & $3(11.1)$ & 0.70 & $5(19.3)$ & $3(11.1)$ & 0.47 \\
\hline 0 & 0 & & $3(11.5)$ & 0 & 0.11 \\
\hline 24 (92.3) & 27 (100) & 0.24 & 26 (100) & 27 (100) & 1.0 \\
\hline $2(7.7)$ & 0 & 0.24 & 0 & 0 & - \\
\hline 20 (76.9) & $23(85.2)$ & 0.5 & 12 (46.2) & $22(81.5)$ & 0.01 \\
\hline $2(7.7)$ & $2(7.4)$ & 1.0 & 7 (26.9) & $3(11.1)$ & 0.17 \\
\hline $4(15.4)$ & $2(7.4)$ & 0.42 & 7 (26.9) & $2(7.4)$ & 0.08 \\
\hline
\end{tabular}

of patients undergoing elective abdominal surgical procedures, the majority lasting more than $2 \mathrm{~h}$ with general anesthesia; notably, both abdominal surgery and longer duration of anesthesia have been reported as potential risk factors for higher incidence of postoperative pulmonary complications $^{1}$; (3) standardization of fluid management during surgery and in the postoperative period, as well as the physiotherapy and analgesic treatments; (4) the chosen endpoints in the postoperative period. From a recent survey in France $^{19}$ the majority ( $>80 \%$ of patients) were managed without PEEP, so the use of ZEEP in the control group might not be considered unsafe for patients. Furthermore, in our study, $20 \%$ of patients underwent hepatic or biliary tract surgery, and some concerns might be also raised with regard to the use of higher PEEP in this specific set of patients during surgery. Thus we believe that the application of ZEEP and $9 \mathrm{ml} / \mathrm{kg}$ tidal volume could have been considered as clinical practice at least in our unit before the study.

Use of higher PEEP levels is potentially associated with an increase in mean airway pressure within the respiratory system, likely promoting higher incidence of hemodynamic complications, higher fluids' requirement, and blood losses.

We used tidal volumes of $9 \mathrm{ml} / \mathrm{kg}$ in the control arm for the following reasons: first, this size of tidal volumes was used as a standard in our institution. Second, previous studies suggested that larger tidal volumes of, e.g., $12 \mathrm{ml} / \mathrm{kg}$ could cause additional lung injury., ${ }^{9,42}$
We found that the use of higher PEEP levels was associated neither with major hemodynamic impairment nor with higher intraoperative requirement of fluids or blood losses. Nevertheless, use of RMs was associated with no life-threatening reductions in systolic arterial pressure and heart rate, but no other complications were observed during RMs.

In the current study we did not use a sustained inflation, as commonly suggested. In fact, sustained inflation might be associated with more deleterious hemodynamic effects. We used a modified RMs by allowing a progressive increase in tidal volumes, which may have promoted less negative hemodynamic impairment.

In the current trial, our aim was not to investigate major postoperative pulmonary complications, but the effects of intraoperative ventilation strategies on relevant clinical parameters associated with alterations in the pulmonary function. We evaluated (1) arterial oxygenation and peripheral oxygen saturation in air, (2) pulmonary functional tests, (3) changes in dyspnea, cough, and secretions, (4) chest $\mathrm{x}$-ray, abnormalities, including atelectasis and pleural effusions, and (5) the mCPIS.

Oxygenation was studied while the patients were breathing in air, in seated position, after $10 \mathrm{~min}$ of adaptation. This allows avoiding any possible influence of different inspiratory oxygen fractions on the arterial oxygenation. The pulmonary functional tests were studied by using a spirometer while the patient was in seated position, allowing reproducible measurements. In our study, we standardized the methods 


\begin{tabular}{|c|c|c|c|}
\hline & \multicolumn{3}{|c|}{ Day 0} \\
\hline & $\begin{array}{l}\text { Standard } \\
\text { Ventilation } \\
(\mathrm{n}=27)\end{array}$ & $\begin{array}{l}\text { Protective } \\
\text { Ventilation } \\
\quad(n=28)\end{array}$ & $P$ Value \\
\hline $\mathrm{FEV}_{1}, \mathrm{I}($ mean $\pm \mathrm{SD})$ & $2.02 \pm 0.78$ & $1.97 \pm 0.68$ & 0.72 \\
\hline $\mathrm{FEV}_{1}(\%$ predicted $), \mathrm{I}($ mean $\pm \mathrm{SD})$ & $77.2 \pm 22.2$ & $75.4 \pm 20.9$ & 0.77 \\
\hline FVC, I (mean \pm SD) & $2.53 \pm 0.86$ & $2.53 \pm 0.80$ & 0.87 \\
\hline FVC (\% predicted), I (mean \pm SD) & $75.9 \pm 2.0$ & $77.5 \pm 18.2$ & 0.85 \\
\hline $\mathrm{FEV}_{1} / \mathrm{FVC}, \%($ mean $\pm \mathrm{SD})$ & $78.3 \pm 11.1$ & $77.1 \pm 13.3$ & 0.74 \\
\hline
\end{tabular}

Values are given as mean and SD.

Group effect was performed by repeated two-way ANOVA. The individual pair-wise comparisons (Bonferroni corrected) show statistical significance as follows: ${ }^{*} P<0.0001$ vs. FEV1 on day $0 .+P<0.0002$ vs. FEV1 on day $0 . \S P<0.0098$ vs. FEV 1 on day $0 .{ }^{*} P<0.0001$ vs. FEV1 (\% predicted) on day $0 .+P<0.0001$ vs. FEV1 (\% predicted) on day $0 . \S P<0.0001$ vs. FEV1 (\% predicted) on day $0 .{ }^{*} P<0.0001$ vs. FVC on day $0 .+P<0.009$ vs. FVC on day $0 . \S P<0.009$ vs. FVC on day $0 .{ }^{*} P<0.0001$ vs. FVC (\% predicted) on day 0.

$\mathrm{FEV} 1$ = forced expiratory volume in $1 \mathrm{~s} ; \mathrm{FVC}=$ forced vital capacity.

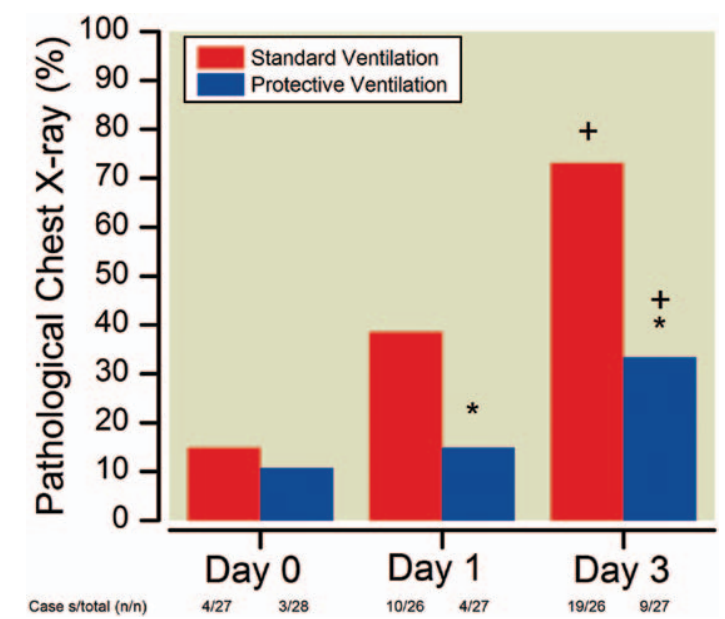

Fig. 5. Pathological chest $x$-ray was defined as the presence of at least one of the following: atelectasis, pleural effusions, or other chest radiological alterations in standard (red bar) and protective (blue bar) ventilation groups. ${ }^{*} P<0.05$ versus standard ventilation group on days 1 and 3 ; within the same group ${ }^{+} P<0.05$ versus preoperative period (day 0). of performing the chest $\mathrm{x}$-ray at the bedside, and the chest $\mathrm{x}$-ray was evaluated by a specialist in radiology, blinded to the study. We used a modified CPIS score, as previously proposed, ${ }^{32}$ as an indicator of pulmonary complications.

In our trial we found that the protective ventilation group was associated with a statistically significant reduction in chest $\mathrm{x}$-ray alterations and mCPIS compared with the standard ventilation group. Especially, chest $\mathrm{x}$-ray showed a clinically significant increase in postoperative atelectasis on both days 1 and 3 in the standard ventilation group. This suggests that patients ventilated with lower tidal volume and no PEEP in our trial could have gross atelectasis and potential peripheral airway injury, caused by tidal airway closure, which was maintained in the postoperative period. Indeed, a recent experimental study in open-chest rabbits, demonstrated that mechanical ventilation with tidal volumes of $8-12 \mathrm{ml} / \mathrm{kg}$ and no PEEP causes permanent mechanical alterations and histologic damage to peripheral airways and inflammation in noninjured lungs. ${ }^{43}$ During general anesthesia, atelectasis is potentiated by anesthesia and muscle relaxants altering diaphragmatic position..$^{5}$ Also, tidal airway closure can occur and cause peripheral

Table 6. Perioperative Organ Functional Tests on Days 1, 3, and 5 Compared with the Preoperative Period (Day 0)

\begin{tabular}{|c|c|c|c|c|c|c|}
\hline & \multicolumn{3}{|c|}{ Day 0} & \multicolumn{3}{|c|}{ Day 1} \\
\hline & $\begin{array}{c}\text { Standard } \\
\text { Ventilation } \\
(n=27)\end{array}$ & $\begin{array}{l}\text { Protective } \\
\text { Ventilation } \\
\quad(n=28)\end{array}$ & $\begin{array}{c}P \\
\text { Value }\end{array}$ & $\begin{array}{l}\text { Standard } \\
\text { Ventilation } \\
(n=26)\end{array}$ & $\begin{array}{l}\text { Protective } \\
\text { Ventilation } \\
\quad(n=27)\end{array}$ & $\begin{array}{c}P \\
\text { Value }\end{array}$ \\
\hline Dyspnea, VAS, median [IQR] & $0[0-0]$ & $0[0-0]$ & 0.82 & $1.0[0-2.0]$ & $1.0[0-1.0]$ & 0.13 \\
\hline Cough, VAS, median [IQR] & $0[0-0]$ & $0[0-0]$ & 0.49 & $2[0-3.0]$ & $1.0[0-2.0]$ & 0.08 \\
\hline Secretions, VAS, median [IQR] & $0[0-0]$ & $0[0-0]$ & 0.64 & $2[1.0-3.0]$ & $1.0[0-2.0]$ & 0.11 \\
\hline Thorax pain, VAS, median [IQR] & $0[0-0]$ & $0[0-0]$ & 1 & $0[0-1.0]$ & $0[0-1.0]$ & 0.67 \\
\hline Abdominal pain, VAS, median [IQR] & $0[0-0]$ & $0[0-0]$ & 0.97 & $2.0[1.0-3.0]$ & $2.0[1.0-3.0]$ & 0.98 \\
\hline Temperature, ${ }^{\circ} \mathrm{C}($ mean $\pm \mathrm{SD})$ & $36.5 \pm 0.4$ & $36.5 \pm 0.3$ & 0.87 & $36.9 \pm 0.7$ & $36.9 \pm 0.4$ & 0.53 \\
\hline Leukocytes, $\mathrm{n} / \mathrm{mm}^{3}$ (mean $\pm \mathrm{SD}$ ) & $6,780 \pm 2,025$ & $6,525 \pm 2,448$ & 0.57 & $11,137 \pm 6,036$ & $9,523 \pm 2,515$ & 0.38 \\
\hline
\end{tabular}

$\mathrm{IQR}=$ interquartile range; VAS = Visual Analogic Scale. 
Table 5. (Continued)

\begin{tabular}{|c|c|c|c|c|c|c|}
\hline \multicolumn{2}{|c|}{ Day 1} & \multicolumn{2}{|c|}{ Day 3} & \multicolumn{2}{|c|}{ Day 5} & \multirow[b]{2}{*}{$\begin{array}{l}\text { Group } \\
\text { Effect } \\
P \text { Value }\end{array}$} \\
\hline $\begin{array}{l}\text { Standard } \\
\text { Ventilation } \\
(n=26)\end{array}$ & $\begin{array}{l}\text { Protective } \\
\text { Ventilation } \\
\quad(n=27)\end{array}$ & $\begin{array}{l}\text { Standard } \\
\text { Ventilation } \\
\quad(n=26)\end{array}$ & $\begin{array}{l}\text { Protective } \\
\text { Ventilation } \\
\quad(n=27)\end{array}$ & $\begin{array}{l}\text { Standard } \\
\text { Ventilation } \\
\quad(n=26)\end{array}$ & $\begin{array}{l}\text { Protective } \\
\text { Ventilation } \\
\quad(n=25)\end{array}$ & \\
\hline $\begin{array}{l}1.00 \pm 0.36^{*} \\
40.2 \pm 13.7^{*}\end{array}$ & $\begin{array}{r}1.18 \pm 0.42^{*} \\
46.48 \pm 17.1^{*}\end{array}$ & $\begin{array}{l}1.14 \pm 0.45+ \\
44.5 \pm 16.4+\end{array}$ & $\begin{array}{l}1.45 \pm 0.51+ \\
56.4 \pm 18.1+\end{array}$ & $\begin{array}{l}1.23 \pm 0.42 \S \\
47.9 \pm 15.7 \S\end{array}$ & $\begin{array}{l}1.63 \pm 0.55 \S \\
62.6 \pm 16.0 \S\end{array}$ & $\begin{array}{r}<0.001 \\
0.002\end{array}$ \\
\hline $1.31 \pm 0.39^{*}$ & $1.48 \pm 0.54^{*}$ & $1.45 \pm 0.46+$ & $1.78 \pm 0.54+$ & $1.57 \pm 0.47 \S$ & $2.02 \pm 0.52 \S$ & $<0.001$ \\
\hline $41.6 \pm 12.1^{*}$ & $47.2 \pm 21.7^{\star}$ & $45.1 \pm 13.3$ & $55.1 \pm 17.9$ & $49.0 \pm 14.3$ & $61.8 \pm 13.4$ & $<0.001$ \\
\hline $75.8 \pm 12.8$ & $82.1 \pm 14.2$ & $77.5 \pm 10.4$ & $81.29 \pm 11.2$ & $77.4 \pm 10.5$ & $78.8 \pm 13.6$ & 0.124 \\
\hline
\end{tabular}

airway injury. This may be a common but unrecognized complication in patients undergoing general anesthesia. ${ }^{44}$ Cyclic opening and closing from ZEEP leads to greater increases in bronchoalveolar lavage cytokines than atelectasis. ${ }^{45}$

Furthermore, these morphological alterations were associated with a marked improvement in arterial oxygenation in air as well as better pulmonary functional tests in the protective ventilation strategy group. Interestingly, in the protective ventilation group compared with the standard ventilation group, on postoperative day 1, we observed a lower percentage of patients with an arterial oxygenation less than 60 mmHg (3.6 vs. $18.5 \%$ respectively). Similarly, we observed a lower percentage of patients with peripheral oxygen saturation levels less than $90 \%$ in air $(3.6$ vs. $19.2 \%$ respectively, $P=$ 0.1 ). Our results suggest therefore that intraoperative protective ventilation strategy may play a relevant role to minimize potential oxygen desaturation in the postoperative period.

Although the study was intentionally not powered for outcome, the improvement in these clinical variables was not associated with a statistically significant reduction in the hospital length of stay in the protective ventilation group. However, in our study, on postoperative day $14,20 \%$ of the patients in the protective ventilation strategy group as compared with $40 \%$ in the standard ventilation strategy group were in hospital.

The current trial suffers of some potential limitations, which need to be addressed. First, our study does not allow to differentiate the effects of lower tidal volumes from those of higher PEEP levels. We deliberately chose to combine lower tidal volumes with higher PEEP levels as well as RMs to identify a ventilation strategy aimed at keeping the lung open during general anesthesia for surgery, a strategy that might have potential benefits in the postoperative period. Second, we performed the RMs until plateau pressure reached $30 \mathrm{~cm} \mathrm{H}$ O for three breaths, but we had not systematically recorded the peak pressures reached during the RM. Third, we did not focus on the effects of ventilation strategies on major postoperative pulmonary complications. The mCPIS includes the evaluation of the chest $\mathrm{x}$-ray. It has been reported that chest $\mathrm{x}$-ray may underestimate the presence of atelectasis and lung morphology alterations as compared with computed tomography. ${ }^{46}$ However, computed tomography is not easy to obtain in this group of patients for technical and ethical

Table 6. (Continued)

\begin{tabular}{|c|c|c|c|c|c|}
\hline \multicolumn{3}{|c|}{ Day 3} & \multicolumn{3}{|c|}{ Day 5} \\
\hline $\begin{array}{l}\text { Standard } \\
\text { Ventilation } \\
(n=26)\end{array}$ & $\begin{array}{l}\text { Protective } \\
\text { Ventilation } \\
\quad(n=27)\end{array}$ & $P$ Value & $\begin{array}{l}\text { Standard } \\
\text { Ventilation } \\
(n=26)\end{array}$ & $\begin{array}{l}\text { Protective } \\
\text { Ventilation } \\
\quad(n=25)\end{array}$ & $P$ Value \\
\hline $1.0[0-2.0]$ & 1.0 [0-1.0] & 0.58 & $1.0[1.0-2.0]$ & 1.0 [0-1.0] & 0.37 \\
\hline 1.0 [0-3.0] & $1.0[0-1.5]$ & 0.16 & $1.0[1.0-2.0]$ & 1.0 [0-2.0] & 0.07 \\
\hline $2.0[1-3.0]$ & $1.0[0-1.5]$ & 0.005 & $1.0[1.0-2.0]$ & 0.5 [0-1.0] & 0.06 \\
\hline 0 [0-0] & 0 [0-0] & 0.75 & 0 [0-1.0] & $0[0-1.0]$ & 0.95 \\
\hline $1.5[1.0-2.0]$ & $2.0[1.0-2.0]$ & 0.78 & $1.0[1.0-2.0]$ & $1.0[1.0-2.0]$ & 0.39 \\
\hline $36.9 \pm 0.6$ & $36.6 \pm 0.4$ & 0.03 & $36.7 \pm 0.5$ & $36.5 \pm 0.3$ & 0.09 \\
\hline $9,548 \pm 3,085$ & $8,877 \pm 2,928$ & 0.29 & $8,623 \pm 2,771$ & $8,386 \pm 2,453$ & 0.73 \\
\hline
\end{tabular}


Table 7. Pathological Chest x-ray Tests on Days 1 and 3 Compared with the Preoperative Period (Day 0)

\begin{tabular}{|c|c|c|c|}
\hline & \multicolumn{3}{|c|}{ Day 0} \\
\hline & $\begin{array}{l}\text { Standard Ventilation } \\
\qquad(\mathrm{n}=27)\end{array}$ & $\begin{array}{l}\text { Protective Ventilation } \\
\qquad(\mathrm{n}=28)\end{array}$ & $P$ Value \\
\hline Normal, n (\%) & 23 & 25 & 0.7 \\
\hline Increased thickness of interstitium, n (\%) & 2 & 2 & 1.0 \\
\hline Disventilatory areas including minimal density change, $\mathrm{n}(\%)$ & 0 & 1 & 1.0 \\
\hline Atelectasis, n (\%) & 0 & 0 & 1.0 \\
\hline Pleural effusions, n (\%) & 2 & 0 & 0.24 \\
\hline
\end{tabular}

Table 8. Postoperative Pulmonary Complications on Days 1 and 3 Compared with the Preoperative Period (Day 0)

\begin{tabular}{|c|c|c|c|c|c|}
\hline & $\begin{array}{l}\text { Standard } \\
\text { Ventilation } \\
(n=27)\end{array}$ & $\begin{array}{l}\text { Protective } \\
\text { Ventilation } \\
(n=28)\end{array}$ & $P$ Value & $\begin{array}{l}\text { Standard } \\
\text { Ventilation } \\
(n=26)\end{array}$ & $\begin{array}{l}\text { Protective } \\
\text { Ventilation } \\
(n=27)\end{array}$ \\
\hline Cough, n (\%) & $2(7.4)$ & $2(7.1)$ & 1.0 & $8(30.8)$ & $4(14.8)$ \\
\hline Increased secretions, n (\%) & $3(11.1)$ & $2(7.1)$ & 0.67 & $10(38.5)$ & $6(22.2)$ \\
\hline Dyspnea, n (\%) & 0 & 0 & - & $8(30.8)$ & $3(11.1)$ \\
\hline Chest pain, n (\%) & 0 & 0 & - & $2(7.7)$ & $1(3.7)$ \\
\hline Temperature $>38^{\circ} \mathrm{C}, \mathrm{n}(\%)$ & 0 & 0 & - & $2(7.7)$ & 0 \\
\hline HR >100 beats/min, $n(\%)$ & 0 & $1(3.6)$ & 1.0 & $3(11.5)$ & 0 \\
\hline
\end{tabular}

$\mathrm{HR}=$ heart rate.

Table 9. Perioperative Laboratory Tests on Days 1, 3, and 5 Compared with the Preoperative Period (Day 0)

\begin{tabular}{|c|c|c|c|c|c|c|}
\hline & \multicolumn{3}{|c|}{ Day 0} & \multicolumn{3}{|c|}{ Day 1} \\
\hline & $\begin{array}{l}\text { Standard } \\
\text { Ventilation } \\
(n=27)\end{array}$ & $\begin{array}{l}\text { Protective } \\
\text { Ventilation } \\
\quad(n=28)\end{array}$ & $\begin{array}{c}P \\
\text { Value }\end{array}$ & $\begin{array}{l}\text { Standard } \\
\text { Ventilation } \\
(n=26)\end{array}$ & $\begin{array}{l}\text { Protective } \\
\text { Ventilation } \\
\quad(n=27)\end{array}$ & $P$ Value \\
\hline Bilirubine, mg/dl (mean \pm SD) & $2.4 \pm 4.2$ & $2.4 \pm 4.6$ & 0.71 & $2.7 \pm 4.9$ & $2.6 \pm 4.4$ & 0.92 \\
\hline AST (mean \pm SD) & $29.9 \pm 22.7$ & $30.7 \pm 25.5$ & 0.53 & $46.2 \pm 46.3$ & $43.4 \pm 40.2$ & 0.81 \\
\hline ALT (mean \pm SD) & $39.0 \pm 45.1$ & $39.6 \pm 52.9$ & 0.46 & $49.9 \pm 51.9$ & $45.2 \pm 37.7$ & 0.77 \\
\hline Platelets, $\mathrm{n} / \mathrm{mm}^{3}$ (mean $\left.\pm \mathrm{SD}\right)$ & $260.8 \pm 92.9$ & $279.3 \pm 112.9$ & 0.63 & $240.5 \pm 78.7$ & $250.1 \pm 104.7$ & 0.79 \\
\hline $\mathrm{PTT}, \mathrm{s}($ mean $\pm \mathrm{SD})$ & $24.9 \pm 2.6$ & $25.9 \pm 2.6$ & 0.27 & $25.18 \pm 3.61$ & $27.3 \pm 5.6$ & 0.04 \\
\hline $\mathrm{PT}, \mathrm{INR}$ (mean $\pm \mathrm{SD}$ ) & $1.0 \pm 0.1$ & $1.1 \pm 0.2$ & 0.85 & $1.2 \pm 0.2$ & $1.2 \pm 0.1$ & 1.0 \\
\hline Serum creatinine, $\mathrm{mg} / \mathrm{dl}($ mean $\pm \mathrm{SD}$ ) & $1.0 \pm 0.1$ & $1.1 \pm 0.3$ & 0.22 & $1.1 \pm 0.2$ & $1.1 \pm 0.4$ & 0.94 \\
\hline
\end{tabular}

ALT = alanine transaminase; $A S T$ = aspartate transaminase; INR = international normalized ratio; PT = prothrombin time; PTT = partial thromboplastin time.

Table 10. Postoperative Fluids Management on Days 1, 2, and 3

\begin{tabular}{|c|c|c|c|}
\hline & \multicolumn{3}{|c|}{ Day 1} \\
\hline & $\begin{array}{l}\text { Standard } \\
\text { Ventilation } \\
(n=26)\end{array}$ & $\begin{array}{l}\text { Protective } \\
\text { Ventilation } \\
\quad(n=27)\end{array}$ & $P$ Value \\
\hline Hydric balance, $\mathrm{ml} \mathrm{kg}^{-1} \mathrm{~h}^{-1}$ (mean $\left.\pm \mathrm{SD}\right)$ & $0.51 \pm 0.32$ & $0.37 \pm 0.41$ & 0.17 \\
\hline Fluid administration, $\mathrm{ml} \mathrm{kg}^{-1} \mathrm{~h}^{-1}$ (mean $\pm \mathrm{SD}$ ) & $1.67 \pm 0.54$ & $1.73 \pm 0.50$ & 0.74 \\
\hline Diuresis, $\mathrm{ml} \mathrm{kg}^{-1} \mathrm{~h}^{-1}$ (mean $\pm \mathrm{SD}$ ) & $1.05 \pm 0.48$ & $1.21 \pm 0.49$ & 0.11 \\
\hline
\end{tabular}


Table 7. (Continued)

\begin{tabular}{|c|c|c|c|c|c|}
\hline \multicolumn{3}{|c|}{ Day 1} & \multicolumn{3}{|c|}{ Day 3} \\
\hline $\begin{array}{l}\text { Standard Ventilation } \\
\qquad(\mathrm{n}=26)\end{array}$ & $\begin{array}{l}\text { Protective Ventilation } \\
\qquad(\mathrm{n}=27)\end{array}$ & $P$ Value & $\begin{array}{l}\text { Standard Ventilation } \\
\qquad(\mathrm{n}=26)\end{array}$ & $\begin{array}{l}\text { Protective Ventilation } \\
\qquad(\mathrm{n}=27)\end{array}$ & $P$ Value \\
\hline 16 & 23 & 0.07 & 7 & 18 & 0.005 \\
\hline 1 & 1 & 1.0 & 3 & 1 & 0.35 \\
\hline 1 & 1 & 1.0 & 4 & 2 & 0.42 \\
\hline 4 & 2 & 0.42 & 7 & 2 & 0.07 \\
\hline 4 & 0 & 0.05 & 5 & 4 & 0.73 \\
\hline
\end{tabular}

Table 8. (Continued)

\begin{tabular}{|c|c|c|c|c|c|c|}
\hline$P$ Value & $\begin{array}{c}\text { Standard } \\
\text { Ventilation } \\
(n=26)\end{array}$ & $\begin{array}{c}\text { Protective } \\
\text { Ventilation } \\
\quad(n=27)\end{array}$ & $P$ Value & $\begin{array}{l}\text { Standard } \\
\text { Ventilation } \\
(n=26)\end{array}$ & $\begin{array}{l}\text { Protective } \\
\text { Ventilation } \\
\quad(n=25)\end{array}$ & $P$ Value \\
\hline 0.20 & 7 (26.9) & 5 (18.5) & 0.53 & 9 (34.6) & 7 (28.0) & 0.76 \\
\hline 0.24 & $12(46.2)$ & 6 (22.2) & 0.09 & $10(38.5)$ & $3(12.0)$ & 0.05 \\
\hline 0.1 & $3(11.5)$ & 5 (18.5) & 0.70 & $2(7.7)$ & 3 (12.0) & 0.67 \\
\hline 0.61 & 0 & $1(3.7)$ & 1.0 & 0 & $1(4.0)$ & 0.49 \\
\hline 0.24 & 1 (3.8) & 0 & 0.49 & $1(3.8)$ & 0 & 1.0 \\
\hline 0.11 & $2(7.7)$ & 0 & 0.23 & 1 (3.8) & 0 & 1.0 \\
\hline
\end{tabular}

Table 9. (Continued)

\begin{tabular}{|c|c|c|c|c|c|}
\hline \multicolumn{3}{|c|}{ Day 3} & \multicolumn{3}{|c|}{ Day 5} \\
\hline $\begin{array}{l}\text { Standard } \\
\text { Ventilation } \\
(n=26)\end{array}$ & $\begin{array}{l}\text { Protective } \\
\text { Ventilation } \\
(n=27)\end{array}$ & $P$ Value & $\begin{array}{l}\text { Standard } \\
\text { Ventilation } \\
(n=26)\end{array}$ & $\begin{array}{l}\text { Protective } \\
\text { Ventilation } \\
\quad(n=25)\end{array}$ & $P$ Value \\
\hline $2.5 \pm 4.6$ & $2.4 \pm 4.5$ & 0.06 & $2.4 \pm 4.0$ & $7.8 \pm 27.8$ & 0.97 \\
\hline $36.2 \pm 23.5$ & $36.4 \pm 40.3$ & 0.33 & $30.3 \pm 17.9$ & $32.6 \pm 20.3$ & 0.55 \\
\hline $37.4 \pm 35.8$ & $47.9 \pm 68.4$ & 0.60 & $33.6 \pm 22.3$ & $42.6 \pm 42.5$ & 0.53 \\
\hline $235.5 \pm 86.3$ & $246.4 \pm 107.7$ & 0.93 & $261.0 \pm 107.1$ & $258.6 \pm 109.7$ & 0.87 \\
\hline $26.8 \pm 2.9$ & $26.2 \pm 2.4$ & 0.19 & $26.9 \pm 3.7$ & $25.3 \pm 5.2$ & 0.47 \\
\hline $1.2 \pm 0.2$ & $1.2 \pm 0.2$ & 0.52 & $1.2 \pm 0.2$ & $1.1 \pm 0.1$ & 0.65 \\
\hline $1.1 \pm 0.3$ & $1.0 \pm 0.4$ & 0.58 & $1.1 \pm 0.3$ & $1.1 \pm 0.3$ & 0.67 \\
\hline
\end{tabular}

Table 10. (Continued)

\begin{tabular}{cccccc}
\hline & Day 2 & & Day 3 \\
\cline { 1 - 2 } $\begin{array}{c}\text { Standard } \\
\begin{array}{c}\text { Ventilation } \\
(\mathrm{n}=26)\end{array}\end{array}$ & $\begin{array}{c}\text { Protective } \\
\text { Ventilation } \\
(\mathrm{n}=27)\end{array}$ & $P$ Value & & $\begin{array}{c}\text { Standard } \\
\text { Ventilation } \\
(\mathrm{n}=26)\end{array}$ & $\begin{array}{c}\text { Protective } \\
\text { Ventilation } \\
(\mathrm{n}=27)\end{array}$ \\
\hline $0.35 \pm 0.46$ & $0.19 \pm 0.45$ & 0.26 & $0.28 \pm 0.38$ & $0.23 \pm 0.50$ & $P$ Value \\
$1.69 \pm 0.54$ & $1.81 \pm 0.52$ & 0.41 & $1.64 \pm 0.53$ & $1.79 \pm 0.52$ & 0.64 \\
$1.22 \pm 0.69$ & $1.46 \pm 0.59$ & 0.09 & $1.21 \pm 0.47$ & $1.42 \pm 0.47$ & 0.06 \\
\hline
\end{tabular}




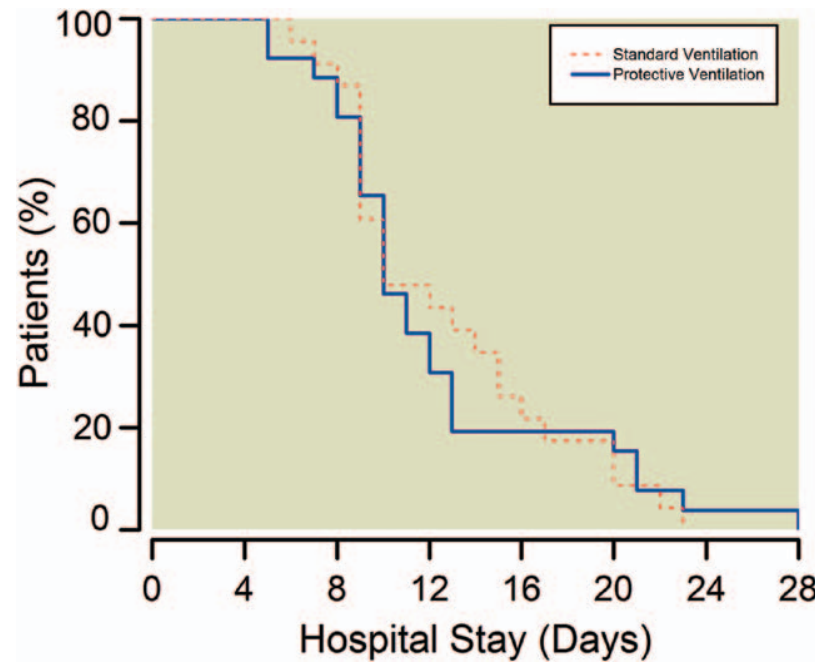

Fig. 6. Hospital length of stay. The Kaplan-Meier curve of length of hospital stay in standard (red dotted line) and protective (blue continuous line) ventilation groups up to day 28; the log-rank test was used for the reported $P$ value.

reasons. Fourth, our data cannot be directly translated to other categories of patients and types of surgery. Fifth, with regard to anesthesia conduction, several studies suggest that volatile anesthetics could modify the inflammatory process in general and we cannot exclude this as having affected our outcomes. Moreover, a recent study shows an induced inflammatory response from halogenated anesthetics versus propofol, which seems to preserve antiinflammatory and antioxidant defences during mechanical ventilation in pigs model, preventing the emergence of apoptosis. ${ }^{47}$ In contrast, several other studies show that halogenated anesthesia attenuates the inflammatory response. ${ }^{48,49}$ Another recent study, concerning the inflammatory response in major abdominal surgery, reveals that there are no statistically significant differences between total intravenous anesthesia and inhalational anesthesia. ${ }^{50}$ Finally, the baseline pulmonary functional test results were a bit lower than predicted, likely due to the method of measurement. However, we believe that this did not affect the interpretation of our data, because we investigated the evolution of pulmonary functional tests with time in the two study groups.

In conclusion, we showed that a protective ventilation strategy with lower tidal volumes, PEEP, and RMs during anesthesia improved the respiratory function in the postoperative period after abdominal nonlaparoscopic surgery and reduced the clinical signs of pulmonary infection during the first 5 days after open abdominal surgery. Larger trials are warranted to determine whether intraoperative protective mechanical ventilation improves major outcome parameters.

\section{References}

1. Smetana GW, Lawrence VA, Cornell JE: Preoperative pulmonary risk stratification for noncardiothoracic surgery: Systematic review for the American College of Physicians. Ann Intern Med 2006; 144:581-95

2. Arozullah AM, Daley J, Henderson WG, Khuri SF: Multifactorial risk index for predicting postoperative respiratory failure in men after major noncardiac surgery. The National Veterans Administration Surgical Quality Improvement Program. Ann Surg 2000; 232:242-53

3. Johnson RG, Arozullah AM, Neumayer L, Henderson WG Hosokawa P, Khuri SF: Multivariable predictors of postoperative respiratory failure after general and vascular surgery: Results from the patient safety in surgery study. J Am Coll Surg 2007; 204:1188-98

4. Finks JF, Osborne NH, Birkmeyer JD: Trends in hospital volume and operative mortality for high-risk surgery. N Engl J Med 2011; 364:2128-37

5. Hedenstierna G, Edmark L: The effects of anesthesia and muscle paralysis on the respiratory system. Intensive Care Med 2005; 31:1327-35

6. Reinius H, Jonsson L, Gustafsson S, Sundbom M, Duvernoy O, Pelosi P, Hedenstierna G, Fredén F: Prevention of atelectasis in morbidly obese patients during general anesthesia and paralysis: A computerized tomography study. ANESTHESIOLOGY 2009; 111:979-87

7. Gajic O, Dara SI, Mendez JL, Adesanya AO, Festic E, Caples SM, Rana R, St Sauver JL, Lymp JF, Afessa B, Hubmayr RD: Ventilator-associated lung injury in patients without acute lung injury at the onset of mechanical ventilation. Crit Care Med 2004; 32:1817-24

8. Gajic O, Frutos-Vivar F, Esteban A, Hubmayr RD, Anzueto A: Ventilator settings as a risk factor for acute respiratory distress syndrome in mechanically ventilated patients. Intensive Care Med 2005; 31:922-6

9. Determann RM, Royakkers A, Wolthuis EK, Vlaar AP, Choi G, Paulus F, Hofstra JJ, de Graaff MJ, Korevaar JC, Schultz MJ: Ventilation with lower tidal volumes as compared with conventional tidal volumes for patients without acute lung injury: A preventive randomized controlled trial. Crit Care 2010; 14:R1

10. Choi G, Wolthuis EK, Bresser P, Levi M, van der Poll T, Dzoljic M, Vroom MB, Schultz MJ: Mechanical ventilation with lower tidal volumes and positive end-expiratory pressure prevents alveolar coagulation in patients without lung injury. ANESTHESIOLOGY 2006; 105:689-95

11. Wolthuis EK, Choi G, Dessing MC, Bresser P, Lutter R, Dzoljic M, van der Poll T, Vroom MB, Hollmann M, Schultz MJ: Mechanical ventilation with lower tidal volumes and positive end-expiratory pressure prevents pulmonary inflammation in patients without preexisting lung injury. Anesthesiology 2008; 108:46-54

12. Schultz MJ: Lung-protective mechanical ventilation with lower tidal volumes in patients not suffering from acute lung injury: A review of clinical studies. Med Sci Monit 2008; 14: RA22-26

13. Sundar S, Novack V, Jervis K, Bender SP, Lerner A, Panzica P, Mahmood F, Malhotra A, Talmor D: Influence of low tidal volume ventilation on time to extubation in cardiac surgical patients. Anesthesiology 2011; 114:1102-10

14. Fernández-Pérez ER, Keegan MT, Brown DR, Hubmayr RD, Gajic $\mathrm{O}$ : Intraoperative tidal volume as a risk factor for respiratory failure after pneumonectomy. ANESTHESIOLOGY 2006; 105:14-8

15. Schultz MJ, Haitsma JJ, Slutsky AS, Gajic O: What tidal volumes should be used in patients without acute lung injury? Anesthesiology 2007; 106:1226-31

16. Wrigge $\mathrm{H}$, Uhlig $\mathrm{U}$, Baumgarten $\mathrm{G}$, Menzenbach J, Zinserling J, Ernst M, Drömann D, Welz A, Uhlig S, Putensen C: Mechanical ventilation strategies and inflammatory responses to cardiac surgery: A prospective randomized clinical trial. Intensive Care Med 2005; 31:1379-87

17. Wrigge $\mathrm{H}$, Uhlig $\mathrm{U}$, Zinserling $\mathrm{J}$, Behrends-Callsen $\mathrm{E}$, Ottersbach G, Fischer M, Uhlig S, Putensen C: The effects of different ventilatory settings on pulmonary and systemic inflammatory responses during major surgery. Anesth Analg 2004; 98:775-81

18. Hong CM, Xu DZ, Lu Q, Cheng Y, Pisarenko V, Doucet D, Brown M, Aisner S, Zhang C, Deitch EA, Delphin E: Low tidal volume and high positive end-expiratory pressure 
mechanical ventilation results in increased inflammation and ventilator-associated lung injury in normal lungs. Anesth Analg 2010; 110:1652-60

19. Jaber S, Coisel Y, Chanques G, Futier E, Constantin JM Michelet P, Beaussier M, Lefrant JY, Allaouchiche B, Capdevila $\mathrm{X}$, Marret E: A multicentre observational study of intra-operative ventilatory management during general anaesthesia: Tidal volumes and relation to body weight. Anaesthesia 2012; 67:999-1008

20. Rothen HU, Sporre B, Engberg G, Wegenius G, Reber A Hedenstierna G: Prevention of atelectasis during general anaesthesia. Lancet 1995; 345:1387-91

21. Girgis K, Hamed H, Khater Y, Kacmarek RM: A decremental PEEP trial identifies the PEEP level that maintains oxygenation after lung recruitment. Respir Care 2006; 51:1132-9

22. Maisch S, Reissmann H, Fuellekrug B, Weismann D, Rutkowski T, Tusman G, Bohm SH: Compliance and dead space fraction indicate an optimal level of positive end-expiratory pressure after recruitment in anesthetized patients Anesth Analg 2008; 106:175-81

23. Kaplan R: ASRA consensus statements for anticoagulated patients. American Society of Regional Anesthesia. Reg Anesth Pain Med 1999; 24:477-8

24. Horlocker TT, Wedel DJ, Benzon H, Brown DL, Enneking FK, Heit JA, Mulroy MF, Rosenquist RW, Rowlingson J, Tryba M, Yuan CS: Regional anesthesia in the anticoagulated patient: Defining the risks (the second ASRA Consensus Conference on Neuraxial Anesthesia and Anticoagulation). Reg Anesth Pain Med 2003; 28:172-97

25. Krombach JW, Dagtekin O, Kampe S: Regional anesthesia and anticoagulation. Curr Opin Anaesthesiol 2004; 17:427-33

26. Horlocker TT, Wedel DJ: Infectious complications of regional anesthesia. Best Pract Res Clin Anaesthesiol 2008; 22:451-75

27. Lawrence VA, Cornell JE, Smetana GW; American College of Physicians: Strategies to reduce postoperative pulmonary complications after noncardiothoracic surgery: Systematic review for the American College of Physicians. Ann Intern Med 2006; 144:596-608

28. Ventilation with lower tidal volumes as compared with traditional tidal volumes for acute lung injury and the acute respiratory distress syndrome. The Acute Respiratory Distress Syndrome Network. N Engl J Med 2000; 342:1301-8

29. Quanjer PH, Tammeling GJ, Cotes JE, Pedersen OF, Peslin R, Yernault JC: Lung volumes and forced ventilatory flows. Report Working Party Standardization of Lung Function Tests, European Community for Steel and Coal. Official Statement of the European Respiratory Society. Eur Respir J Suppl 1993; 16:5-40

30. Gastpar H, Criscuolo D, Dieterich HA: Efficacy and tolerability of glaucine as an antitussive agent. Curr Med Res Opin 1984; 9:21-7

31. Vernon $\mathrm{M}$, Kline Leidy $\mathrm{N}$, Nacson A, Nelsen L: Measuring cough severity: Development and pilot testing of a new seven-item cough severity patient-reported outcome measure. Ther Adv Respir Dis 2010; 4:199-208

32. Pelosi P, Barassi A, Severgnini P, Gomiero B, Finazzi S, Merlini G, d'Eril GM, Chiaranda M, Niederman MS: Prognostic role of clinical and laboratory criteria to identify early ventilatorassociated pneumonia in brain injury. Chest 2008; 134:101-8

33. Vincent JL, de Mendonça A, Cantraine F, Moreno R, Takala J, Suter PM, Sprung CL, Colardyn F, Blecher S: Use of the SOFA score to assess the incidence of organ dysfunction/failure in intensive care units: Results of a multicenter, prospective study. Working group on "sepsis-related problems" of the European Society of Intensive Care Medicine. Crit Care Med 1998; 26:1793-800

34. Celli BR, Rodriguez KS, Snider GL: A controlled trial of intermittent positive pressure breathing, incentive spirometry, and deep breathing exercises in preventing pulmonary complications after abdominal surgery. Am Rev Respir Dis 1984; 130:12-5
35. Horan TC, Gaynes RP, Martone WJ, Jarvis WR, Emori TG: CDC definitions of nosocomial surgical site infections, 1992: A modification of CDC definitions of surgical wound infections. Infect Control Hosp Epidemiol 1992; 13:606-8

36. Michelet P, D'Journo XB, Roch A, Doddoli C, Marin V, Papazian L, Decamps I, Bregeon F, Thomas P, Auffray JP: Protective ventilation influences systemic inflammation after esophagectomy: A randomized controlled study. AnEsthesiology 2006; 105:911-9

37. Koner O, Celebi S, Balci H, Cetin G, Karaoglu K, Cakar $\mathrm{N}$ : Effects of protective and conventional mechanical ventilation on pulmonary function and systemic cytokine release after cardiopulmonary bypass. Intensive Care Med 2004; 30:620-6

38. Reis Miranda D, Gommers D, Struijs A, Dekker R, Mekel J, Feelders R, Lachmann B, Bogers AJ: Ventilation according to the open lung concept attenuates pulmonary inflammatory response in cardiac surgery. Eur J Cardiothorac Surg 2005; 28:889-95

39. Zupancich E, Paparella D, Turani F, Munch C, Rossi A, Massaccesi S, Ranieri VM: Mechanical ventilation affects inflammatory mediators in patients undergoing cardiopulmonary bypass for cardiac surgery: A randomized clinical trial. J Thorac Cardiovasc Surg 2005; 130:378-83

40. Wrigge H, Zinserling J, Stüber F, von Spiegel T, Hering R, Wetegrove S, Hoeft A, Putensen C: Effects of mechanical ventilation on release of cytokines into systemic circulation in patients with normal pulmonary function. ANESTHESIOLOGY 2000; 93:1413-7

41. Reis Miranda D, Struijs A, Koetsier P, van Thiel R, Schepp R, Hop W, Klein J, Lachmann B, Bogers AJ, Gommers D: Open lung ventilation improves functional residual capacity after extubation in cardiac surgery. Crit Care Med 2005; 33:2253-8

42. Treschan TA, Kaisers W, Schaefer MS, Bastin B, Schmalz U, Wania V, Eisenberger CF, Saleh A, Weiss M, Schmitz A, Kienbaum P, Sessler DI, Pannen B, Beiderlinden M: Ventilation with low tidal volumes during upper abdominal surgery does not improve postoperative lung function. Br J Anaesth 2012; 109:263-71

43. D'Angelo E, Pecchiari M, Gentile G: Dependence of lung injury on surface tension during low-volume ventilation in normal open-chest rabbits. J Appl Physiol 2007; 102:174-82

44. Hedenstierna G: Alveolar collapse and closure of airways: Regular effects of anaesthesia. Clin Physiol Funct Imaging 2003; 23:123-9

45. Duggan M, McNamara PJ, Engelberts D, Pace-Asciak C Babyn P, Post M, Kavanagh BP: Oxygen attenuates atelectasis-induced injury in the in vivo rat lung. ANESTHESIOLOGY 2005; 103:522-31

46. Gregoretti C, Pelosi P: A physiologically oriented approach to the perioperative period: The role of the anaesthesiologist. Best Pract Res Clin Anaesthesiol 2010; 24:vii-viii

47. Kalimeris K, Christodoulaki K, Karakitsos P, Batistatou A, Lekka M, Bai M, Kitsiouli E, Nakos G, Kostopanagiotou G: Influence of propofol and volatile anaesthetics on the inflammatory response in the ventilated lung. Acta Anaesthesiol Scand $2011 ; 55: 740-8$

48. Schilling T, Kozian A, Kretzschmar M, Huth C, Welte T, Bühling F, Hedenstierna G, Hachenberg T: Effects of propofol and desflurane anaesthesia on the alveolar inflammatory response to one-lung ventilation. Br J Anaesth 2007; 99:368-75

49. Lee JJ, Kim GH, Kim JA, Yang M, Ahn HJ, Sim WS, Park KJ, Jun BH: Comparison of pulmonary morbidity using sevoflurane or propofol-remifentanil anesthesia in an Ivor Lewis operation. J Cardiothorac Vasc Anesth 2012; 26:857-62

50. Kvarnström AL, Sarbinowski RT, Bengtson JP, Jacobsson LM, Bengtsson AL: Complement activation and interleukin response in major abdominal surgery. Scand J Immunol 2012; 75:510-6 